\title{
Generation of Recombinant, Enzymatically Active Human Thyroid Peroxidase and its Recognition by Antibodies in the Sera of Patients with Hashimoto's Thyroiditis
}

Keith D. Kaufman, Basil Rapoport, Pui Seto, Gregorio D. Chazenbalk, and Ronald P. Magnusson

The University of California, San Francisco, and Thyroid Molecular Biology Laboratory (111T),

Veterans' Administration Medical Center, San Francisco, California 94121

\section{Abstract}

A full-length cDNA clone for human thyroid peroxidase (TPO) inserted into the mammalian cell expression vector pECE was stably transfected into Chinese hamster ovary (CHO) cells. Clones were assayed for human TPO mRNA, TPO protein, and TPO enzymatic activity. One subclone, expressing the highest TPO enzymatic activity, was used in further studies. FACS analysis of these cells preincubated in Hashimoto's serum revealed approximately 100-fold greater fluorescence compared with controls, indicating that recombinant TPO is expressed on the cell surface. Particulate antigen was extracted from these cells and studied by Western blot analysis using a panel of Hashimoto's sera of known antimicrosomal antibody (anti-MSA) titer. Under nonreducing conditions a broad, immunoreactive band of $\sim 200 \mathrm{kD}$ was observed, as well as a doublet of $\sim 110 \mathrm{kD}$. All of the 36 Hashimoto's sera tested reacted with these bands, most in proportion to their anti-MSA titer. Six normal sera tested against this antigen(s) were nonreactive, as were the Hashimoto's sera tested against nontransfected CHO cells. Western blots under reducing conditions revealed a considerably diminished signal, with some of the sera of lower anti-MSA titer becoming negative, the loss of the 200-kD broad band, and the apparent conversion of the 110-kD doublet into a single band. Preincubation of cells in tunicamycin revealed no decrease in TPO immunoreactivity.

In conclusion, we expressed enzymatically active human TPO in nonthyroidal eukaryotic cells. Our data prove that functionally active TPO is a major component of the thyroid microsomal antigen.

\section{Introduction}

Hashimoto's thyroiditis is the most common autoimmune endocrinopathy, affecting, at least subclinically, up to $15 \%$ of the adult female population $(1,2)$. Antibodies against a number of thyroid antigens are present in the sera of these patients, including thyroglobulin and the thyroid microsomal antigen (3, 4). Other antigens of lesser or uncertain importance include the second colloid antigen (3), tubulin (5), DNA (6), and au-

Dr. Magnusson's present address is Department of Pharmacology, Mt. Sinai School of Medicine, New York, NY.

Address correspondence to Dr. Basil Rapoport, Thyroid Molecular Biology Laboratory (111T), Veterans' Administration Medical Center, 4150 Clement Street, San Francisco, CA 94121.

Received for publication 25 January 1989 and in revised form 27 March 1989.

The Journal of Clinical Investigation, Inc.

Volume 84, August 1989, 394-403 toimmune thyroid disease-related antigen I (7). Antibodies against the microsomal antigen, which is expressed on the cell surface $(8,9)$, are believed to be of greater importance than those against thyroglobulin in the pathogenesis of Hashimoto's thyroiditis. This is because antimicrosomal antibodies (antiMSA) ${ }^{1}$ are more closely associated with the active phase of the disease $(1,10,11)$ and are complement fixing $(8)$. These antibodies are, therefore, likely to initiate thyroid cellular damage.

A major recent discovery regarding Hashimoto's thyroiditis is that the previously ill-defined microsomal antigen is, at least in part, thyroid peroxidase (TPO), the primary enzyme involved in thyroid hormone synthesis. This conclusion was based on immunologic evidence (12-15) and subsequently confirmed by the molecular cloning of the cDNA for these proteins (16-19) and the discovery that their derived amino acid sequences are the same $(18,20)$.

Until the present time, a suitable preparation of recombinant TPO has not been available for studies on the presumed abnormalities in immune regulation in Hashimoto's thyroiditis or for the demonstration of the specific $B$ and $T$ cell epitopes involved in this disease. In this respect, understanding of the molecular mechanisms involved in the pathogenesis of Hashimoto's thyroiditis lags far behind that of myasthenia gravis, a disease for which pure antigen (the acetylcholine receptor) has been obtained and epitopes already defined (21, 22). Human TPO immunopurified by MAbs has been available but is of limited value because of $(a)$ inadequate supplies of human thyroid tissue; $(b)$ the difficulties in purification of this membrane-bound antigen; and (c) contamination with other thyroid autoantigens such as thyroglobulin, which is highly abundant. Fragments of human TPO have been generated as recombinant bacterial fusion proteins (18). These, too, have been of limited value because $(a)$ no combination of fragments has been found that react with all Hashimoto's sera; (b) the conformation of the fusion protein may differ from that of the native protein; and $(c)$ the bacterial products may be toxic when added to immune cells in culture.

To obtain full-length human TPO free of other potential thyroid antigens for studying the pathogenesis of Hashimoto's thyroiditis, we attempted the expression of recombinant human TPO in nonthyroidal eukaryotic cells. Like native human TPO, this recombinant TPO is enzymatically active, is expressed on the cell surface, and is not a fusion protein. We demonstrate further that this protein is recognized in a specific manner by sera from patients with Hashimoto's thyroiditis that contain anti-MSA.

1. Abbreviations used in this paper: $\mathrm{CHO}$, Chinese hamster ovary; anti-MSA, antimicrosomal antibodies; TBS, Tris-buffered saline; TPO, thyroid peroxidase. 


\section{Methods}

Construction of a human Graves' thyroid cDNA library. A thyroid cDNA library was constructed to maximize the inclusion of full-length cDNA in the coding orientation. Hyperplastic thyroid tissue was obtained from a patient undergoing thyroidectomy for Graves' disease. mRNA was isolated according to the method of Han et al. (23). Double-stranded cDNA was synthesized from $15 \mu \mathrm{g}$ mRNA as described by Gubler and Hoffman (24). Not I and Xba I linker-primers/adaptors were incorporated into the cDNA to create those restriction sites at the $5^{\prime}$ and $3^{\prime}$ ends, respectively, of the cDNA (23). The cDNA was size selected ( $>1 \mathrm{~kb}$ ) by agarose gel (Seaplaque; FMC, Rockland, ME) electrophoresis, digested with Not I and Xba I, ligated into Not I- and Xba I-cut bacteriophage lambda-Zap using T4 DNA ligase, and packaged (Giga-Pak Gold; Stratagene, San Diego, CA). The resulting phage library contained a total of $2 \times 10^{4}$ recombinant clones before amplification.

Screening for full-length human TPO $c D N A$. The amplified cDNA library was plated at a density of $4 \times 10^{4}$ plaque-forming units per 150-mm-diam dish and probed using the insert from a partial human TPO cDNA clone (clone 19, reference 17). Two positive bacteriophage clones were isolated. A Bluescript phagemid containing the human TPO cDNA insert was generated from one of these clones using the helper phage R408, according to the Stratagene protocol. The resulting recombinant Bluescript plasmid (pHTPO-BS) contained bases $5-3,060$ of human TPO cDNA, including the start of translation and the poly-A tail. DNA sequence was determined from this double- stranded plasmid using the Sequenase kit and protocol (United States Biochemical Corp., Cleveland, $\mathrm{OH}$ ). Sequence within the cDNA was confirmed to be identical to human TPO cDNA at the $5^{\prime}$ and $3^{\prime}$ ends and in the regions adjacent to 10 oligonucleotide primers distributed throughout the CDNA (17).

Construction of pHTPO-ECE. The mammalian cell expression vector pECE (25) was obtained from Dr. William Rutter (University of California, San Francisco). Human TPO cDNA was cloned into the multiple cloning site of this vector as described in Fig. 1. Enzyme reactions and DNA manipulations were performed as described in Maniatis et al. (26).

Transfection of Chinese hamster ovary (CHO) cells with pHTPOECE. CHO cell line CHO-K1 was maintained in Ham's F-12 medium supplemented with $10 \%$ fetal bovine serum, penicillin $(125 \mathrm{U} / \mathrm{ml})$, streptomycin $(100 \mu \mathrm{g} / \mathrm{ml})$, and amphotericin-B $(2.5 \mu \mathrm{g} / \mathrm{ml})$. Transfection and selection with G-418 (Gibco Laboratories, Grand Island, NY) was carried out by the method of Chen and Okayama (27). $20 \mu \mathrm{g}$ pHTPO-ECE plus $2 \mu \mathrm{g}$ pSV2-neo (28) (from Dr. John Baxter, University of California, San Francisco) were used for the transfection. Control transfections with $20 \mu \mathrm{g}$ pECE plus $2 \mu \mathrm{g} \mathrm{pSV} 2-n e o$, and $20 \mu \mathrm{g}$ pSV2-neo alone, were performed concurrently.

RNA extraction and Northern blot analysis. Total cellular RNA was extracted by the method of Chomczynski and Sacchi (29). $15 \mu \mathrm{g}$ of RNA was electrophoresed in formaldehyde gels as described by Maniatis et al. (26). RNA was blotted onto a Zeta-Probe membrane (BioRad Laboratories, Richmond, CA) and probed with a $0.56-\mathrm{kb}$ human TPO cDNA probe (clone 31 insert, reference 17), labeled to a sp act of
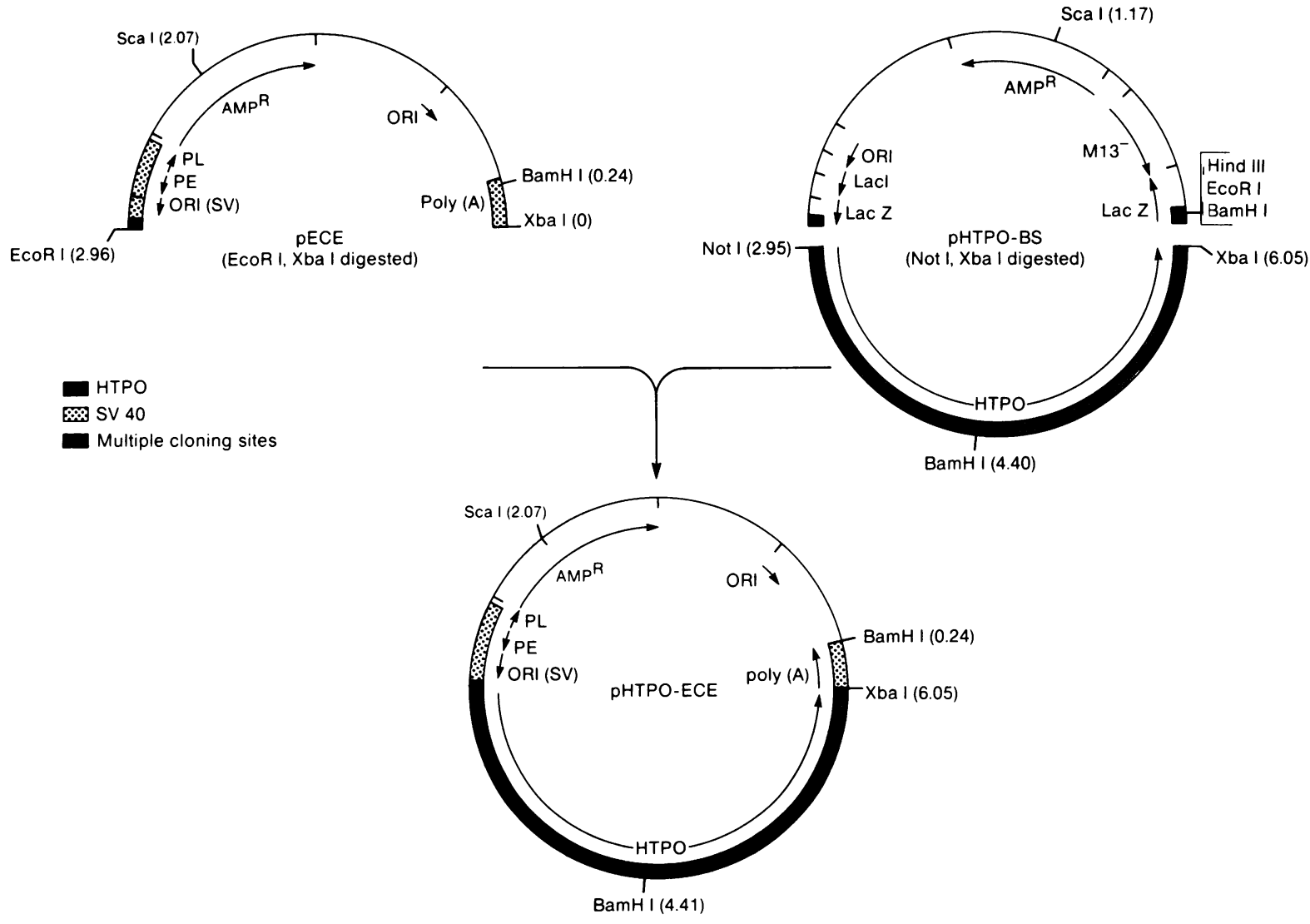

Figure 1. Construction of the expression plasmid pHTPO-ECE. pHTPO-BS (upper right) was digested with Not I, the ends were blunted with the Klenow fragment of DNA polymerase I, and the DNA was subsequently digested with Xba I. The released Bluescript vector was further digested with Sca I to obtain good separation on agarose gel electrophoresis because of the similar size of this vector $(2.95 \mathrm{~kb})$ and the HTPO cDNA fragment ( $3.1 \mathrm{~kb}$ ). The mammalian expression vector pECE (25) (upper left) was digested with Eco RI, the ends were blunted with the Klenow fragment of DNA polymerase I, and the DNA was subsequently digested with Xba I. The digested pHTPO-BS and pECE fragments were then ligated using T4 DNA ligase (26). The resulting plasmid, pHTPO-ECE (bottom), was transfected into competent XL1-blue cells (Stratagene, San Diego, CA). 
$4 \times 10^{9} \mathrm{cpm} / \mu \mathrm{g}$ DNA using the Multi-Prime labeling kit (Amersham Corp., Arlington Heights, IL).

Western blot analysis. Transfected CHO cells were extracted to obtain soluble protein. Five 100-mm-diam dishes were washed three times with calcium-magnesium-free Dulbecco's PBS. After aspiration, $5 \mathrm{ml}$ of $0.5 \%$ Triton X-100 in the same buffer, supplemented with 10 $\mu \mathrm{g} / \mathrm{ml}$ leupeptin, $0.5 \mathrm{mg} / \mathrm{ml}$ bacitracin, and $2 \mathrm{mM}$ PMSF (all from Sigma Chemical Co., St. Louis, MO), was added to the first dish. This initial cell solution was scraped and transferred successively to the other four dishes of cells. The cell solution was then tumbled for $1 \mathrm{~h}$ at $4^{\circ} \mathrm{C}$. After centrifugation for $3 \mathrm{~min}$ at $10,000 \mathrm{~g}$ the supernatant was saved and stored at $-20^{\circ} \mathrm{C}$ until use. Protein content was determined (30) and $50 \mu \mathrm{g}$ protein/lane electrophoresed on a $7.5 \%$ polyacrylamide SDS gel (31). Proteins were electrotransferred ( $30 \mathrm{~V}$ for $5 \mathrm{~h}$, or $250 \mathrm{~mA}$ overnight) to nitrocellulose membranes (Schleicher \& Schuell, Inc., Keene, NH) in an electroblotting apparatus (Hoeffer Scientific Instruments, San Francisco, CA) containing $25 \mathrm{mM}$ Tris, $192 \mathrm{mM}$ glycine, and $20 \%$ methanol. In later experiments transfer was accomplished using a Polyblot semidry electrotransfer system (American Bionetic, Hayward, CA) according to the directions of the manufacturer. Membranes were rinsed once in Tris-buffered saline $(0.1 \mathrm{M}$ Tris, $\mathrm{pH} 8.0$, $0.15 \mathrm{M} \mathrm{NaCl}$; TBS), then for 30-60 min at room temperature in TBS containing $0.5 \%$ Tween 20 (Sigma Chemical Co.). After three further rinses with TBS-Tween the blots were probed as described by Young and Davis (32) using a 1:250 dilution of a mouse MAb against the thyroid microsomal antigen (33), followed by a 1:250 dilution of horseradish peroxidase-conjugated goat anti-mouse IgG antibody (Sigma Chemical Co.). In later experiments CHO-HTPO12b (see Results) cell extracts were probed using a panel of polyclonal Hashimoto's thyroiditis sera, kindly provided by Dr. S. M. McLachlan (University of Wales, Cardiff). Anti-MSA titers had previously been determined by ELISA in the presence of excess thyroglobulin (11). Multiple Hashimoto's thyroiditis sera (diluted 1:400 in TBS-Tween unless described otherwise in the text) were applied to a single filter overnight at $4^{\circ} \mathrm{C}$ using a Miniblotter 45 manifold (Immunetics, Cambridge, MA). Membranes were then processed as described above, except that alkaline phosphatase-conjugated goat anti-human IgG, Fc fragment-specific (Cappel Laboratories, Cochranville, PA), was used as the second antibody with nitroblue tetrazolium $(0.3 \mathrm{mg} / \mathrm{ml})$ and 5-bromo-4chloro-3-indolyl-phosphate $(0.15 \mathrm{mg} / \mathrm{ml})$ in $100 \mathrm{mM}$ Tris, pH 9.5, 100 $\mathrm{mM} \mathrm{NaCl}$, and $5 \mathrm{mM} \mathrm{MgCl} 2$.

FACS analysis. CHO-HTPO12b cells were processed as described by Ellis et al. (25). In brief, cells from a 100 -mm-diam dish were detached by mild trypsinization, and the cells rinsed and pelleted ( 5 min at $100 \mathrm{~g}, 4^{\circ} \mathrm{C}$ ) in Ham's F-12 medium and $10 \%$ FCS (see above). The cells were resuspended in $0.2 \mathrm{ml}$ of PBS, $10 \mathrm{mM}$ Hepes, $\mathrm{pH} 7.4$, $0.05 \% \mathrm{Na}$ azide (buffer A). Serum to be tested $(2 \mu \mathrm{l})$ was added for 30 min at $4^{\circ} \mathrm{C}$, followed by two rinses in buffer A with $2 \%$ FCS and resuspension in $0.2 \mathrm{ml}$ of the same solution. $25 \mu \mathrm{l}$ of goat anti-human IgG, Fc specific, affinity purified, R-phycoerythrin labeled (Caltag, South San Francisco, CA), was added for another 30 min at $4^{\circ} \mathrm{C}$. After three washes in buffer $A$ the cells were analyzed on a FACS.

Assay of human TPO enzymatic activity. Human TPO activity was assayed after extraction from cell microsomes with trypsin and deoxycholate as previously described (34). In later experiments a more rapid method was used. Cells were suspended with a rubber scraper in $1.5 \mathrm{ml}$ calcium-magnesium-free PBS and protein was determined on a 5- $\mu \mathrm{l}$ aliquot. The cells were then pelleted in a microcentrifuge for $2 \mathrm{~min}$. Cold $0.1 \%$ deoxycholate $(0.2 \mathrm{ml} / \mathrm{mg}$ cellular protein) was added for 10 $\mathrm{min}$. The extract was microcentrifuged for $5 \mathrm{~min}$ and the supernatant removed for assay. One guaiacol unit is defined as a $\Delta \mathrm{A}_{470}$ of $1.0 / \mathrm{min}$, which is equivalent to $150 \mathrm{nmol}$ guaiacol oxidized/min (35). One unit of iodide peroxidase is defined as a $\Delta \mathrm{A}_{353}$ of $1.0 / \mathrm{min}$, which corresponds to $43 \mathrm{nmol} \mathrm{I}_{3}^{-}$formed/min (36).

Primary culture of human Graves' disease thyroid cells. Human Graves' disease thyroid tissue was dispersed and the cells were cultured as previously described (37). After $3 \mathrm{~d}$ in culture, fresh medium containing $12.5 \mathrm{mU} / \mathrm{ml}$ thyroid-stimulating hormone (TSH) was added for an additional $3 \mathrm{~d}$ before the cells were harvested and extracted as for the Western blots described above.

Enzymes. Restriction enzymes, T4 DNA ligase, and DNA polymerase I, Klenow fragment were obtained alternatively from Bethesda Research Laboratories (Gaithersburg, MD), New England Biolabs (Beverly, MA), or Boehringer-Mannheim Biochemicals (Indianapolis, IN).

\section{Results}

Because multiple screenings of our previously constructed human thyroid cDNA library in lambda gt 11 (17) only yielded fragments of TPO cDNA, we constructed a new thyroid cDNA library in lambda-Zap, as described in Methods. The plasmid pHTPO-BS containing full-length human TPO cDNA was obtained from this library. pHTPO-ECE was constructed from pHTPO-BS and the mammalian expression vector pECE (25) according to the strategy shown in Fig. 1, and was used for subsequent cell transfections.

CHO cells were cotransfected with pHTPO-ECE and pSV2-neo, and 12 clones were tested for the presence of TPO mRNA by Northern blot analysis. Four of these clones, as well as one of four control (pSV2-neo alone) clones, are shown in Fig. $2 A$, and reveal a 3.3-kb mRNA band in the pHTPOECE-transfected clones. The size of the human TPO mRNA in the transfected $\mathrm{CHO}$ cells is slightly larger than that in the Graves' thyroid cells $(3.1 \mathrm{~kb})$, presumably because of the additional SV40 poly-A coding region at the $3^{\prime}$ end of human TPO cDNA in the pHTPO-ECE plasmid (see Fig. 1).

Western blot analysis (under reducing conditions) of proteins extracted from TPO-transfected $\mathrm{CHO}$ cells using a mouse monoclonal anti-human thyroid microsomal antibody (33) revealed an immunoreactive protein of $105-110 \mathrm{kD}$, as expected for human TPO $(12,38)$ (Fig. $2 \mathrm{~B}$ ).

Strong TPO enzymatic activity was evident in clone $\mathrm{CHO}-$ HTPO 12 and in subclones CHO-HTPO12b and CHOHTPO12g, obtained by limiting dilution (Table I). Less enzymatic activity was detected in the other clones (data not shown). TPO activity in the CHO-HTPO12 clones was approximately the same as TPO activity in TSH-stimulated Graves' thyroid cells in monolayer culture (Table I).

To determine whether, as with native TPO in thyroid cells, the recombinant human TPO was expressed on the surface of the $\mathrm{CHO}$ cells transfected with this gene, CHO-HTPO12b cells were subjected to FACS analysis (Fig. 3). Incubation of these cells with high-titer anti-MSA Hashimoto's serum (ELISA value of 1.772 ; normal $<0.2)(11)$ yielded approximately 100 fold greater fluorescence than when these cells were incubated with control serum (Fig. 3). Similar results were obtained with three different Hashimoto's sera (data not shown). The size of both the control and Hashimoto's serum-incubated cells was the same (Fig. 3, $E$ and $F$ ), excluding the possibility that differences in cell size were, in part, responsible for the differences in signal.

A series of Western blot studies were then performed with protein from CHO-HTPO12b cells using a panel of Hashimoto's sera with known anti-MSA levels as determined by ELISA (11). Under nonreducing conditions, all 29 Hashimoto's sera tested, unlike three normal sera, reacted with a major, broad protein band of $\sim 200 \mathrm{kD}$, as well as with a fainter doublet of $\sim 110 \mathrm{kD}$ (Fig. 4). In aggregate, in studies performed under nonreducing conditions, a total of $36 \mathrm{Hashi-}$ 


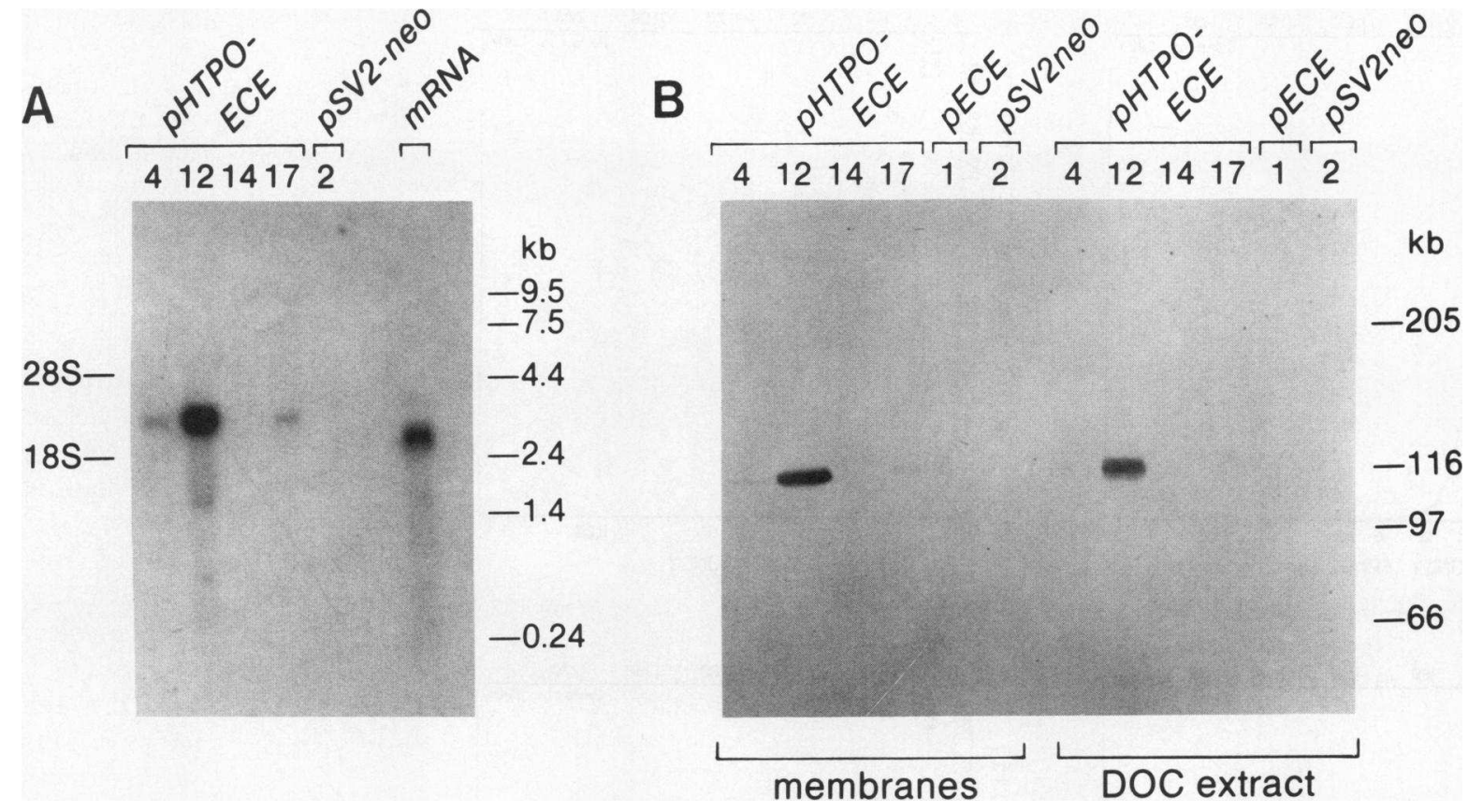

Figure 2. Northern and Western blot analyses of RNA and protein, respectively, from transfected cell lines. $(A)$ Northern blot. Total cellular RNA (15 $\mu \mathrm{g} /$ lane) from four pHTPO-ECE transfected cell lines (CHO-HTPO4, CHO-HTPO12, CHO-HTPO14, and CHO-HTPO17) and one control pSV2-neo transfected cell line (CHO-pSV2-neo), was subjected to Northern blot analysis using a human TPO cDNA probe as described in Methods. For comparison, $1 \mu \mathrm{g}$ of poly A+ mRNA prepared from a human thyroid gland from a patient with Graves' disease was applied to the lane on the far right $(m R N A)$. $28 S$ and $18 S$ represent ribosomal RNA markers, and an RNA molecular weight ladder (Bethesda Research Laboratories, Gaithersburg, MD) is shown on the right of the panel. (B) Western blot analysis. $50 \mu \mathrm{g}$ of membrane protein or $30 \mu \mathrm{g}$ of deoxycholate (DOC)-extracted protein (Methods) from pHTPO-ECE-transfected cell lines (CHO-HTPO4, CHO-HTPO12, CHO-HTPO14, and CHO-HTPO17), from a control cell line cotransfected with pECE and pSV2-neo, and from another control cell line transfected with pSV2-neo alone, were subjected to SDS-PAGE under reducing conditions. The proteins were electrotransferred to nitrocellulose membranes and then probed, as described in Methods, with a mouse MAb against the thyroid microsomal antigen (33).

moto's sera tested, but not 6 control sera, reacted with these bands. The interexperimental variability in the intensity of these bands, however, as well as methodological limitations in analyzing many samples simultaneously, precluded comparison of results of all samples tested. Nevertheless, it is apparent that within a single large experiment (Fig. 4) the strongest

Table I. TPO Activity in CHO-HTPO12 Cells and in TSHstimulated, Graves' Human Thyroid Cell Primary Cultures

\begin{tabular}{lcc}
\hline \multicolumn{1}{c}{ Cell type } & Guaiacol peroxidase & Iodide peroxidase \\
\hline CHO-pECE (control) & U/mg protein & $U / m g$ protein \\
CHO-pSV2-neo (control) & 0 & 0 \\
Human thyroid cells & 0 & 0 \\
& 4.7 & 3.0 \\
CHO-HTPO12 & 4.6 & 3.4 \\
CHO-HTPO12b & 3.6 & $\mathrm{ND}$ \\
CHO-HTPO12g & 4.0 & 3.1 \\
& 3.1 & 1.9 \\
\hline
\end{tabular}

Summary of data from multiple determinations of guaiacol and iodide TPO activity measured in deoxycholate extracts (see Methods) prepared from 100-mm-diam dishes of the indicated cells. Graves' disease-affected human thyroid cells were cultured for $3 \mathrm{~d}$ in 12.5 $\mathrm{mU} / \mathrm{ml}$ human TSH. signals are seen with sera containing the highest anti-MSA ELISA values. Some sera also recognize protein bands other than those expected for TPO (Fig. 4, lanes 5 and 22). These bands represent wild-type $\mathrm{CHO}$ antigens (presented below). The apparent TPO-specific signal of $110 \mathrm{kD}$ in lane 24 is also a nonspecific wild-type $\mathrm{CHO}$ signal (presented below).

Comparison of the recombinant TPO signals on Western blots performed under reducing and nonreducing conditions (Fig. 5) revealed the following with reduction: $(a)$ loss of the $200-\mathrm{kD}$ broad band; $(b)$ alteration of the $110-\mathrm{kD}$ signal so that it no longer clearly represents a doublet; and $(c)$ lessening of the specific signals so that some of the weaker sera become negative. The nonimmune serum that reacts with a band of $\sim 110 \mathrm{kD}$ (Fig. 5, lane 6) is the same serum used in Fig. 4, lane 24. This band represents a wild-type $\mathrm{CHO}$ protein, and not TPO (presented below). The nonspecific $\mathrm{CHO}$ proteins bound by some of the sera tested are more evident in Fig. 5 than in Fig. 4 because a more intense colorimetric development led to a higher background.

The specificity of the 200- and 110-kD bands discussed above was demonstrated in two separate experiments using wild-type, non-TPO-transfected CHO cells (Fig. 6). In the first experiment (left) selected, potent Hashimoto's sera tested under the most favorable (i.e., nonreducing) conditions failed to react with protein bands of 200 or $110 \mathrm{kD}$. Of note are the strong nonspecific signals of lower molecular weight seen with the serum used in lane 3 (the same serum used in Fig. 4, lane 

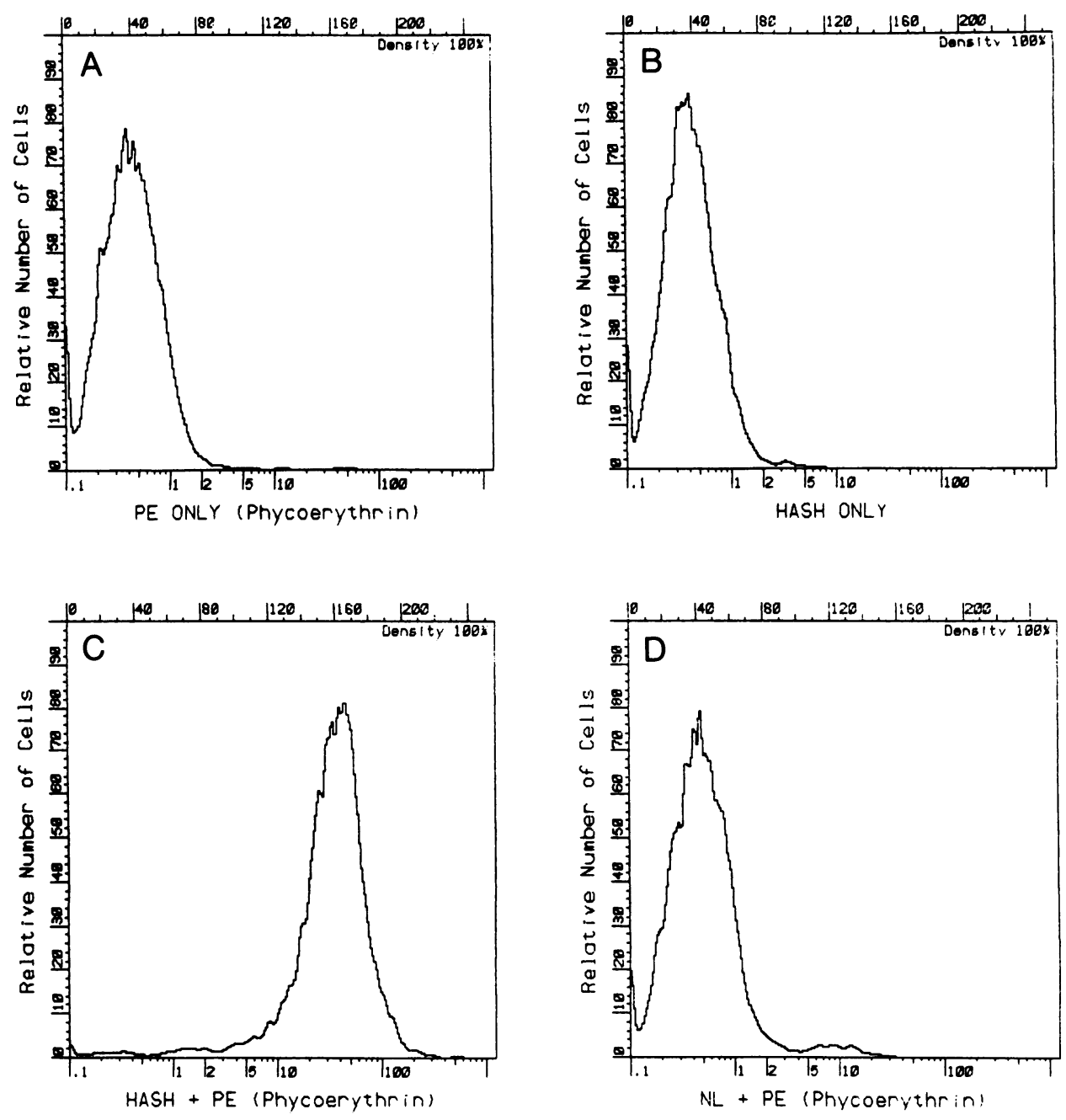

Figure 3. FACS analysis of $\mathrm{CHO}$ cells transfected with pHTPOECE. CHO-HTPO12b cells were processed as described in Methods. $(A)$ Cells exposed to phycoerythrin $(P E)$-labeled second antibody alone, without prior exposure to human serum. (B)
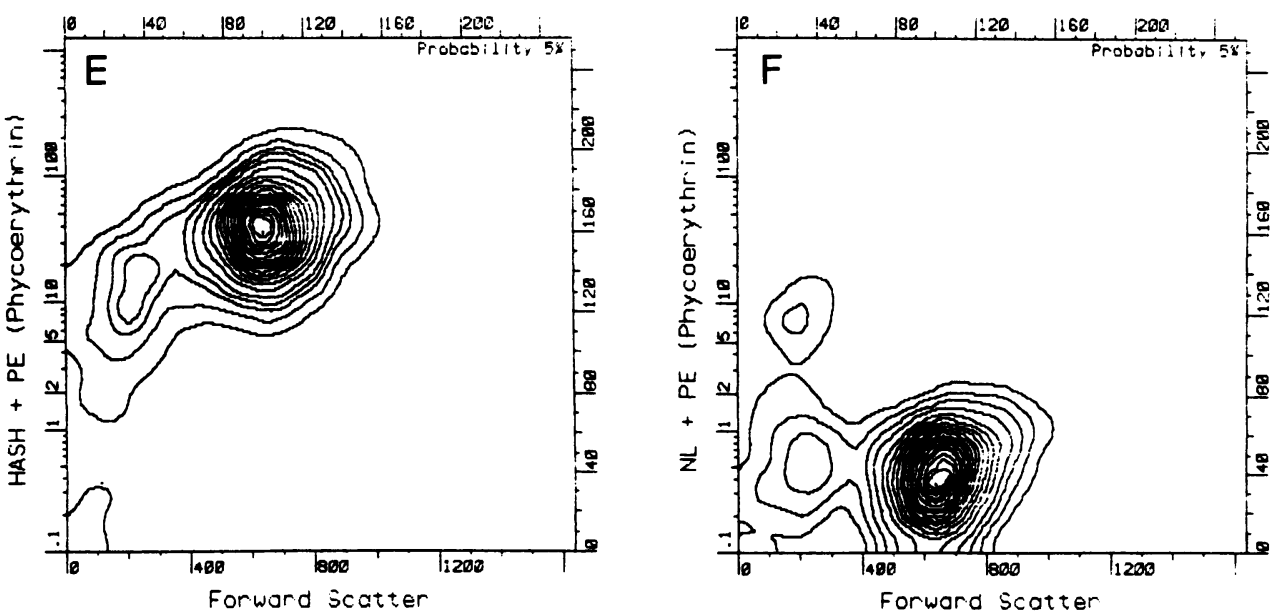

Cells incubated in serum (1:100) from a patient with Hashimoto's thyroiditis (ELISA value of 1.779) without subsequent incubation in PE-labeled second antibody. $(C)$

Cells sequentially incubated in the Hashimoto's serum described in $B$ and in PE-labeled second antibody. (D) As in $C$, except that serum from a normal individual, lacking anti-MSA, was used. $(E)$ and $(F)$ The same data as in $C$ and $D$ plotted to show the forward scatter. These data indicate that the relative sizes of the cell populations reacting with the normal and the Hashimoto's sera are the same.

22). The second experiment (right) indicates that the nonimmune serum previously shown to react with a band of $110 \mathrm{kD}$ (Fig. 4, lane 24 and Fig. 5, lane 6) is a false positive. This signal in wild-type $\mathrm{CHO}$ cells is strong despite the use of unfavorable (i.e., reducing) conditions. Nonspecific $\mathrm{CHO}$ cell-reactive proteins appear stronger in Fig. 6 because the colorimetric reaction was continued for a longer period of time to empha- size the lack of specific signals in these control, non-TPO-containing cells.

To assess the sensitivity of detection of the specific signal, Western blot analyses were performed with serial dilutions of two Hashimoto's sera. The amount of TPO generated in CHO-HTPO12b cells is sufficient to be detected even when these Hashimoto's sera were diluted $>3,000$-fold (Fig. 7). 


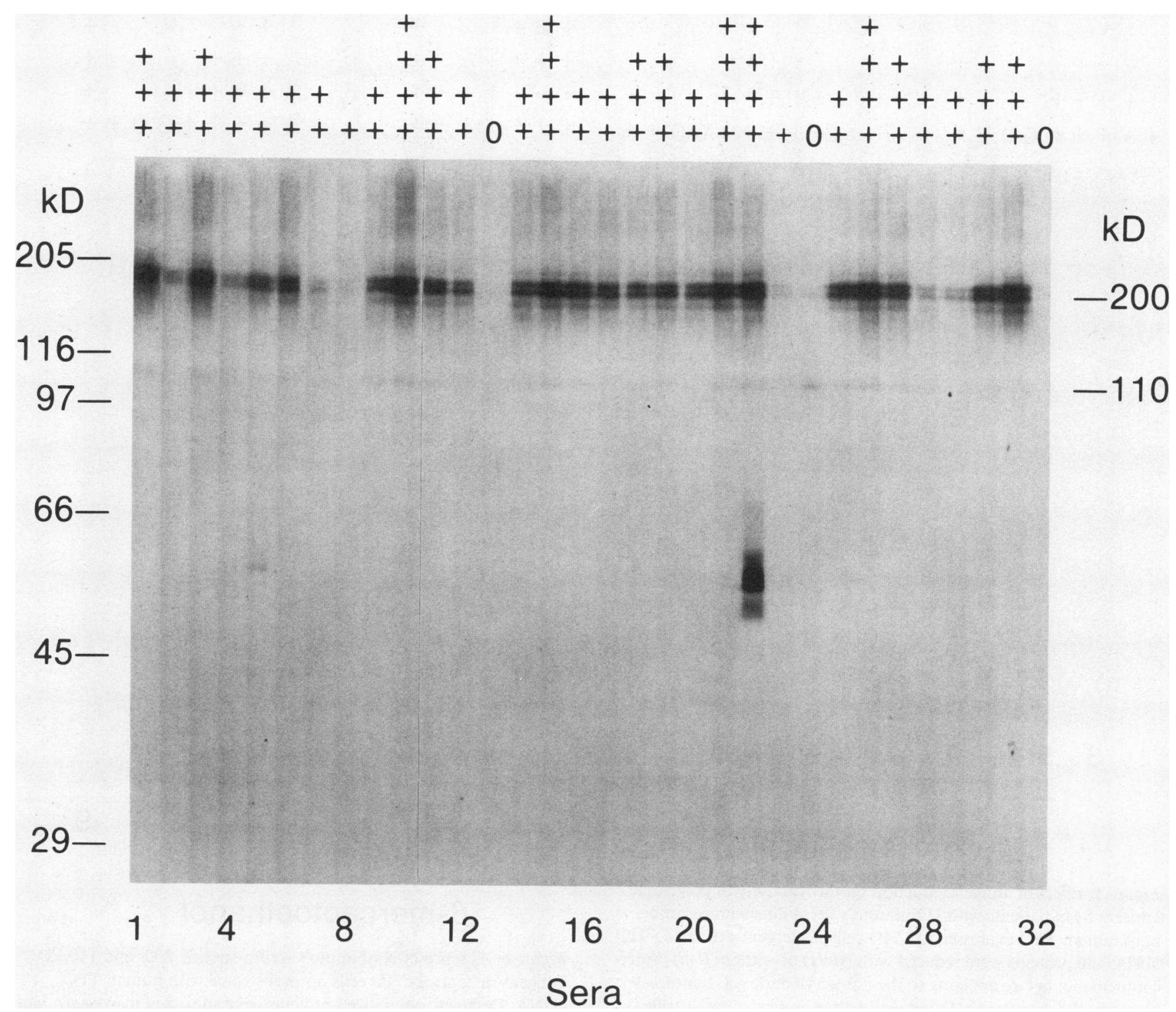

Figure 4. Reactivity of a panel of sera from patients with Hashimoto's thyroiditis with antigens in human TPO-transfected CHO cells. CHOHTPO12b cells were processed and subjected to Western blot analysis as described in Methods. Lanes 1-32 represent different sera of known anti-MSA levels as determined by ELISA. ELISA values are represented by the pluses at the top of each lane: $0,<0.2$ OD units; +, 0.2-0.5 OD units;,$++ 0.5-1.0$ OD units;,$+++ 1.0-1.5$ OD units;,$++++>1.5$ OD units. Thus, lanes 13,24 , and 32 represent normal sera. The size of the reacting proteins is indicated relative to the molecular weight markers (in kilodaltons): 205 , myosin; $116, \beta$-galactosidase; 97 , phosphorylase b; 66 , bovine albumin; 45 , ovalbumin; and 29 , carbonic anhydrase.

Human TPO contains five potential glycosylation sites. We therefore examined whether carbohydrate moieties were important in the conformation of the epitope(s) in the human TPO antigen(s) recognized by Hashimoto's sera. Western blot analyses were performed on proteins extracted from $\mathrm{CHO}-$ HTPO $12 \mathrm{~b}$ cells precultured for $20 \mathrm{~h}$ in $0.5 \mu \mathrm{g} / \mathrm{ml}$ tunicamycin, an inhibitor of protein glycosylation. This length of time was chosen because it was the longest tolerated without evidence of significant toxicity (i.e., cell loss). Tunicamycin treatment had no apparent effect on antigen recognition (Fig. 8), suggesting that carbohydrate moieties may not be important components of the microsomal antigen epitope(s). The mark in lane 4 (left) is an artifact. In a control experiment tunicamycin treatment under similar conditions decreased radiolabeled D-glucosamine incorporation into proteins by $56.3 \pm 4.8 \%$ (mean \pm SD; $n=3$ ).

\section{Discussion}

The present data provide a number of important advances in the characterization of the human thyroid microsomal antigen, and open the way to substantial further developments in this field. We have generated recombinant, enzymatically active human TPO in nonthyroidal eukaryotic cells. Unlike a bacterial fusion protein, the conformation of this protein is not encumbered by $\beta$-galactosidase and the protein can be glyco- 

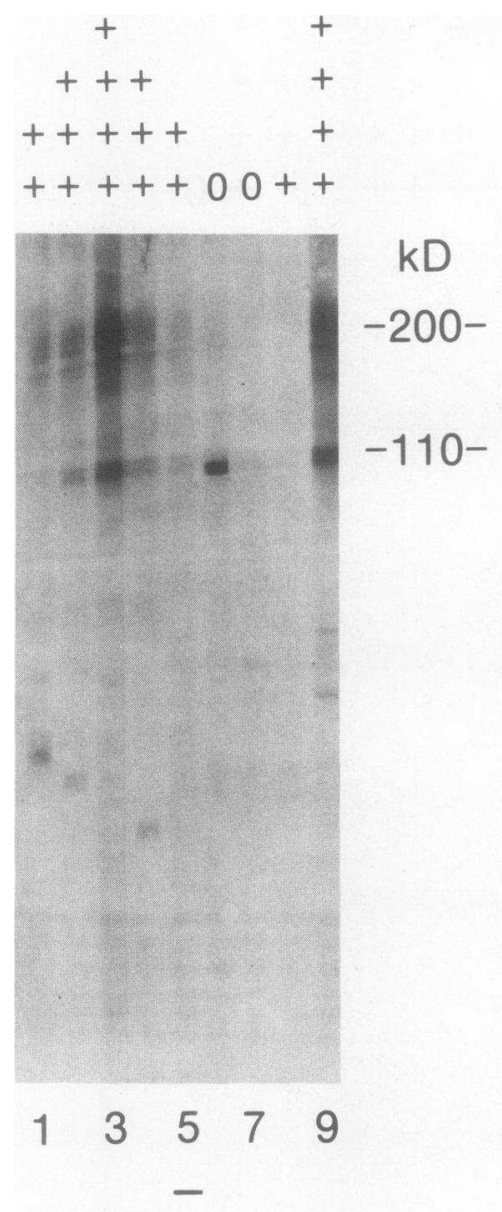

\section{$\beta$-mercaptoethanol}

Figure 5. Effect of antigen reduction on the reactivity of polyclonal antisera from patients with Hashimoto's thyroiditis with recombinant human TPO expressed in CHO cells. Detergent-extracted CHOHTPO12b proteins were reduced with (right) or without (left) $\beta$-mercaptoethanol before applying to the polyacrylamide gel. Lanes 1-9 represent different sera with anti-MSA titers indicated by the pluses above each lane, according to the scale described in the legend to Fig. 4. The same sera were used in the indicated lanes in each panel. In this and subsequent figures sizing of the reacting proteins was based on the molecular weight markers shown in Fig. 4.

sylated. The demonstration of functional TPO activity indicates unequivocally that the cDNA previously cloned by our laboratory $(16,17)$, as well as those of others $(18,19)$, is indeed TPO.

Experiments with this recombinant TPO protein expressed in a nonthyroidal eukaryotic cell prove that TPO, independent of any other potential thyroid antigen, is a major autoantigen in Hashimoto's thyroiditis. Thus, all 36 Hashimoto's sera tested reacted specifically with recombinant human TPO in an approximately quantitative manner as demonstrated by Western blot analysis. While previous immunological studies strongly suggested that anti-MSA react with human TPO (12-15), it was difficult to exclude the possibility of contamination of immunopurified antigen by other, unidentified, thyroid antigens. The only thyroidal (or, indeed, human) protein
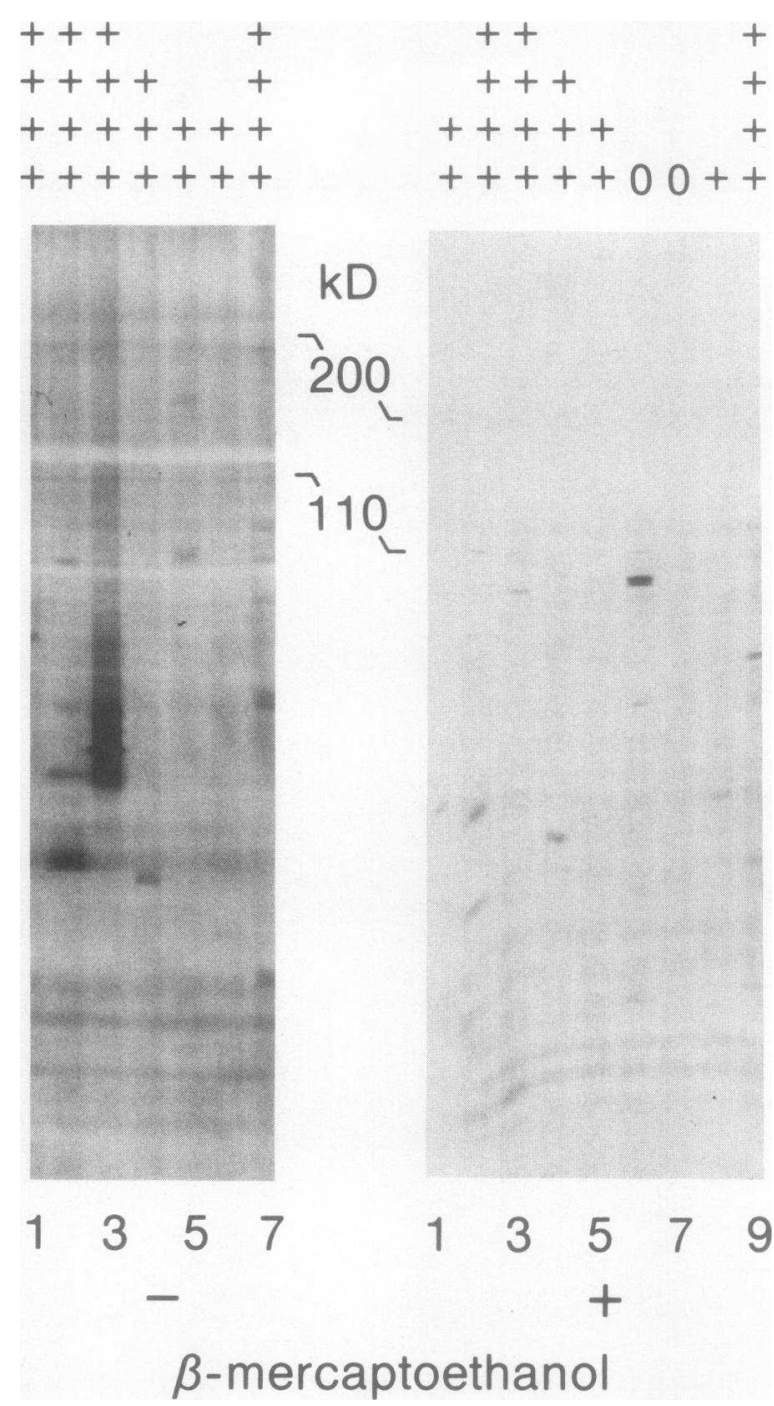

Figure 6. Absence of Hashimoto's serum-specific 200- and 110-kD antigens in control $\mathrm{CHO}$ cells not transfected with human TPO cDNA. Detergent-solubilized proteins were subjected to Western blot analysis as described in Methods. Each panel represents a separate experiment. Proteins were (right) or were not (left) pretreated with $\beta$ mercaptoethanol as described in the legend to Fig. 5 . The numbers at the bottom of each lane represent individual sera. The anti-MSA titers are represented by pluses, as described in the legend to Fig. 4 . The left panel shows that selected, highly potent antisera are nonreactive under nonreducing conditions (where the signal is expected to be maximum; see Fig. 5). The experiment in the right panel includes control sera to accentuate reactivity with wild-type CHO proteins under reducing conditions (where specific signals are expected to be diminished; see Fig. 5).

in the CHO-HTPO cells is human TPO. Even though human sera from both normal subjects and patients with Hashimoto's thyroiditis contain antibodies that react with some $\mathrm{CHO}$ cell antigens, only the Hashimoto's patents' sera react with the recombinant human TPO.

Libert and co-workers have demonstrated the reactivity of a number of Hashimoto's sera with small fragments of TPO expressed as $\beta$-galactosidase fusion proteins (18). Those data, however, are difficult to interpret because the plaque assays 


\section{Dilution (Fold)}
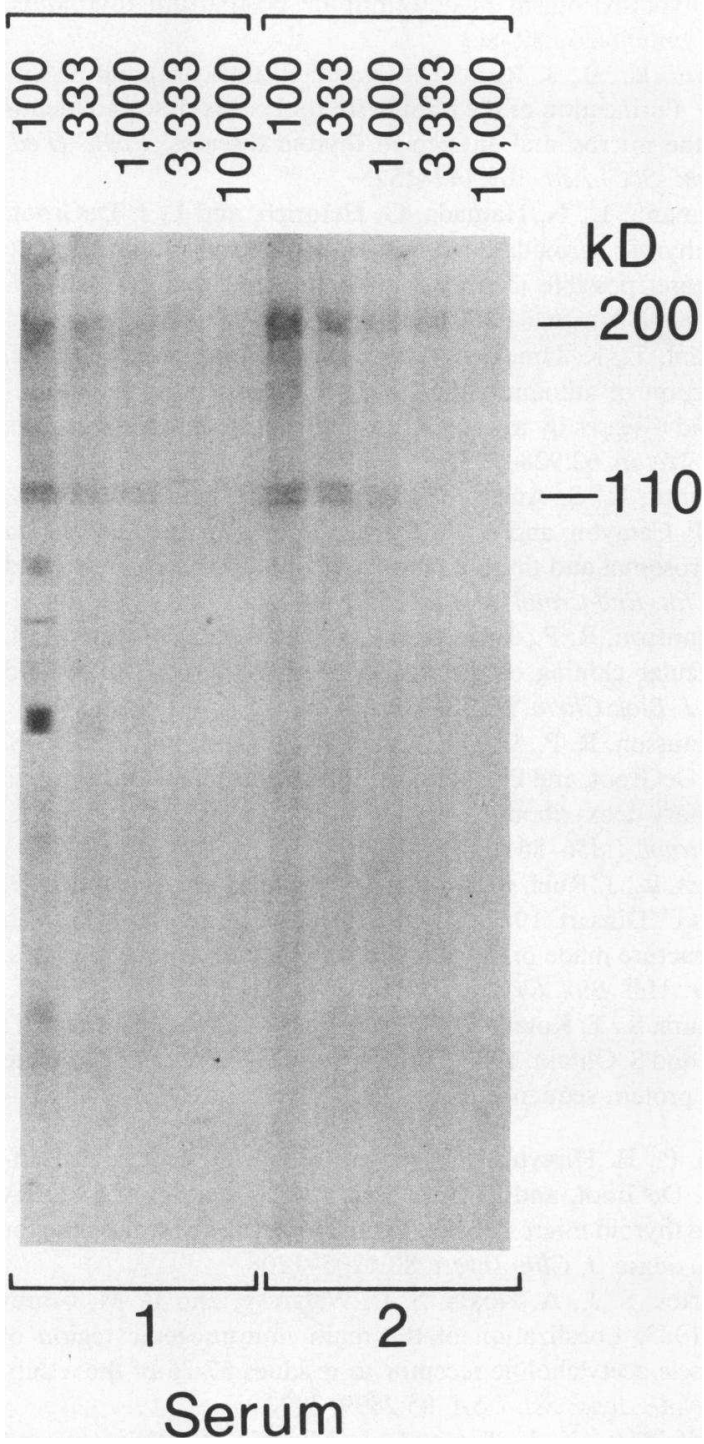

Figure 7. Sensitivity of the detection of recombinant human TPO in CHO cells by Western blot analysis. Two separate Hashimoto's sera with ELISA readings of 1.827 (left) and 1.772 OD units (right) were used at the indicated dilutions. Sizes of the reacting bands were estimated relative to molecular weight markers (see legend to Fig. 4).

used require extensive preadsorption of polyclonal antisera (7) and can yield false positive results. For example, a reported fusion protein originally described as reactive with 19 of 20 Hashimoto's sera (reference 18, clone $\mathrm{C} 2$ ) has, upon immunopurification with anti- $\beta$-galactosidase MAbs, been found to react with fewer Hashimoto's sera in an ELISA assay (39). In the present study, using eukaryotic recombinant TPO, we show that all 36 Hashimoto's sera, selected to represent a range of anti-MSA levels seen in this disease, were reactive.

Our data also shed light on previous observations that the microsomal antigen may appear as a doublet on PAGE and Western blot analysis $(33,40,41)$. It was unclear whether this doublet represented two separate proteins or the partial degradative product of a single protein. Kimura et al. observed two

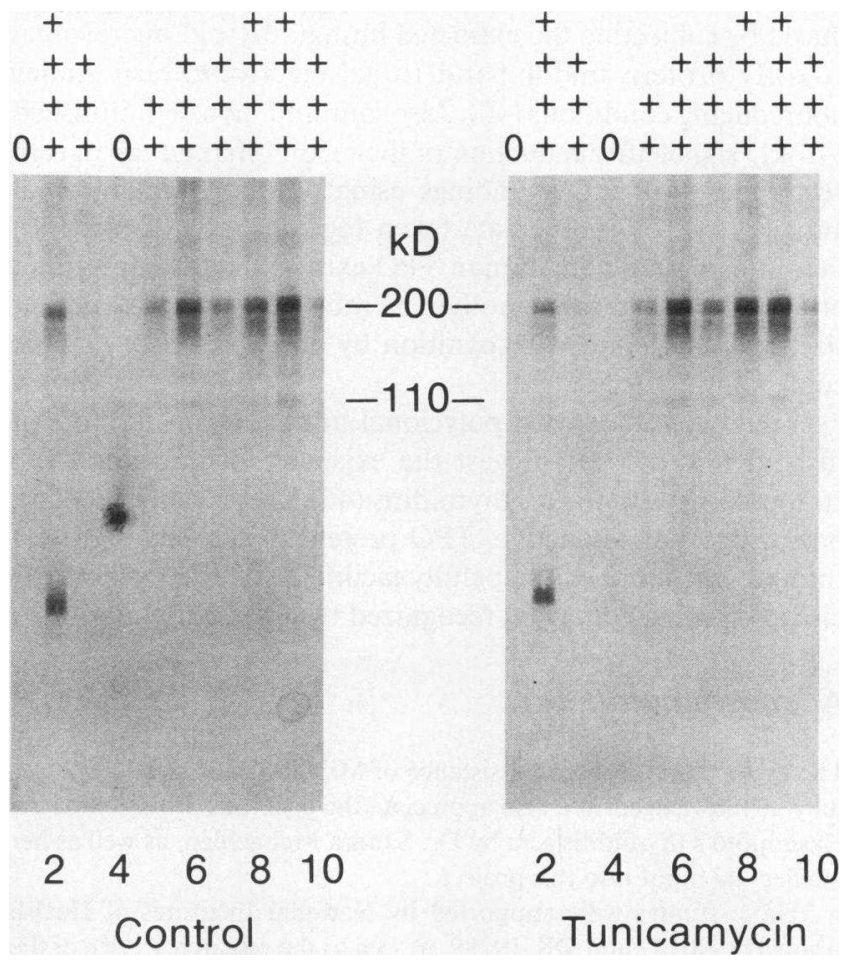

Figure 8. Lack of effect of tunicamycin on the antigenicity of recombinant human TPO expressed in CHO cells. CHO-HTPO12b cells were cultured for $20 \mathrm{~h}$ with (right) or without (left) $0.5 \mu \mathrm{g} / \mathrm{ml}$ tunicamycin before Western blot analysis of detergent-extracted proteins as described in Methods. Each lane is numbered to indicate the use of a separate serum, with MSA ELISA values indicated by the pluses above each lane according to the scale described in the legend to Fig. 4. The same sera were used in each panel. The mark in lane 4, left panel, is an artifact.

forms of human TPO mRNA and CDNA and suggested the possibility of alternate splicing of the initial TPO transcripts (19). Nagayama et al. reported the existence of four different forms of human TPO mRNA transcripts in cultured Graves' thyroid cells after TSH stimulation (42). Our finding of a doublet as the product of a single, intronless, human TPO gene provides strong evidence against the likelihood of alternate splicing as the cause of the doublet.

The apparent conversion of the doublet to a single band after protein reduction, reminiscent of the data of Portmann et al. with a crude human thyroid extract (33), suggests that membrane-bound human TPO is linked through disulfide bonds to another, unidentified protein. An alternate interpretation, in line with the model of Yokoyama and Taurog (43), is that intrachain disulfide bonds exist within TPO, and that these may alter the migratory behavior of TPO on a gel, yielding the appearance of multiple forms. Unlike data obtained using human thyroid microsomes in which the primary antigen (under nonreducing conditions) was $107 \mathrm{kD}$ in size (40), we observed under the same conditions that the major immunogenic form of recombinant human TPO in CHO cells is $\sim 200 \mathrm{kD}$, which disappears upon reduction to a band of $\sim 110 \mathrm{kD}$. This difference may be related to varied expression of human TPO in different cell types (human and CHO). However, it was also reported that a $200-\mathrm{kD}$ protein was pro- 
duced by subjecting the extracted human thyroid microsomal 107-kD protein major band to gel electrophoresis under nonreducing conditions (40). Also, our finding of a diminished $110-\mathrm{kD}$ signal after reduction of the recombinant antigen is in accordance with other findings using the native microsomal antigen $(44,45)$. These data taken together provide evidence that in its native state human TPO exists either as a multimer or in association with another membrane protein of similar size, and that epitope recognition by autoantibodies may be conformation dependent.

Finally, studies with polyclonal antibodies using human thyroid microsomes suggest the existence of multiple TPO epitopes in Hashimoto's thyroiditis (46). Our generation of an intact, functionally active, TPO protein that reacts with Hashimoto's antisera will hopefully facilitate studies to define the disease-specific epitope(s) recognized by autoantibodies.

\section{Acknowledgments}

The expert administrative assistance of Mr. Gil dela Calzada is gratefully acknowledged. We also appreciate the generous provision of the Hashimoto's thyroiditis sera by Dr. Sandra McLachlan, as well as her intellectual input into this project.

These studies were supported by National Institutes of Health grants DK-36182 and DK-19289, as well as the research service of the Veterans' Administration.

\section{References}

1. Volpe, R. 1986. Autoimmune thyroiditis. In The Thyroid. S. H. Ingbar and L. E. Braverman, editors. 5th ed. J. B. Lippincott Co., Philadelphia. 1266-1291.

2. Gordin, A., J. Maatela, A. Miettinen, T. Helenius, and B. A. Lamberg. 1979. Serum thyrotrophin and circulating thyroglobulin and thyroid microsomal antibodies in a Finnish population. Acta Endocrinol. 90:33-42.

3. Doniach, D., G. F. Bottazzo, and R. C. G. Russell. 1979. Goitrous autoimmune thyroiditis (Hashimoto's Disease). Clin. Endocrinol. Metab. 8:63-80.

4. Weetman, A. P., and A. M. McGregor. 1984. Autoimmune thyroid disease: developments in our understanding. Endocr. Rev. 5:309-355.

5. Rousset, B., F. Bernier-Valentin, C. Poncet, J. Orgiazzi, A. Madec, J. C. Monier, and R. Mornex. 1983. Anti-tubulin antibodies in autoimmune thyroid disorders. Clin. Exp. Immunol. 52:325-332.

6. Katakura, M., T. Yamada, T. Aizawa, K. Hiramatsu, Y. Yukimura, M. Ishihara, N. Takasu, K. Maruyama, M. Kameko, M. Kanai, and I. Kobayashi. 1987. Presence of antideoxyribonucleic acid antibody in patients with hyperthyroidism of Graves' Disease. J. Clin. Endocrinol. Metab. 64:405-408.

7. Hirayu, H., P. Seto, R. P. Magnusson, S. Filetti, and B. Rapoport. 1987. Molecular cloning and partial characterization of a new autoimmune thyroid disease-related antigen. J. Clin. Endocrinol. Metab. 64:578-584.

8. Khoury, E. L., L. Hammond, G. F. Bottazzo, and D. Doniach. 1981. Presence of organ-specific "microsomal" autoantigen on the surface of human thyroid cells in culture: its involvement in complement-medicated cytotoxicity. Exp. Immunol. 45:316-328.

9. Nilsson, M., J. Molne, F. A. Karlsson, and L. E. Ericson. 1987. Immunoelectron microscopic studies on the cell surface location of the thyroid microsomal antigen. Mol. Cell. Endocrinol. 53:177-186.

10. Bogner, U., H. Schleusener, and J. R. Wall. 1984. Antibodydependent cell-mediated cytotoxicity against human thyroid cells in Hashimoto's thyroiditis but not Graves' disease. J. Clin. Endocrinol. Metab. 59:734-738.
11. Jansson, R., P. M. Thompson, F. Clark, and S. M. McLachlan. 1986. Association between thyroid microsomal antibodies of subclass IgG-1 and hypothyroidism in autoimmune postpartum thyroiditis. Clin. Exp. Immunol. 63:80-86.

12. Czarnocka, B., J. Ruf, M. Ferrand, P. Carayon, and S. Lissitzky. 1985. Purification of the human thyroid peroxidase and identification as the microsomal antigen in thyroid diseases. FEBS (Fed. Eur. Biochem. Soc.) Lett. 109:147-152.

13. Portmann, L., N. Hamada, G. Heinrich, and L. J. DeGroot. 1985. Anti-thyroid peroxidase antibody in patients with autoimmune thyroid disease: possible identity with antimicrosomal antibody. $J$. Clin. Endocrinol. Metab. 61:1001-1003.

14. Kotani, T., K. Umeki, S. Matsunga, E. Kato, and S. Ohtaki. 1986. Detection of autoantibodies to thyroid peroxidase in autoimmune thyroid diseases by micro-ELISA and immunoblotting. J. Clin. Endocrinol. Metab. 62:928-933.

15. Mariotti, S., S. Anelli, J. Ruf, R. Bechi, B. Czarnocka, A. Lombardi, P. Carayon, and A. Pinchera. 1987. Comparison of serum thyroid microsomal and thyroid peroxidase autoantibodies in thyroid disease. J. Clin. Endocrinol. Metab. 65:987-993.

16. Magnusson, R. P., J. Gestautas, A. Taurog, and B. Rapoport. 1987. Molecular cloning of the structural gene for porcine thyroid peroxidase. J. Biol. Chem. 262:13885-13888.

17. Magnusson, R. P., G. D. Chazenbalk, J. Gestautas, P. Seto, S. Filetti, L. J. DeGroot, and B. Rapoport. 1987. Molecular cloning of the complementary deoxyribonucleic acid for human thyroid peroxidase. Mol. Endocrinol. 1:856-861.

18. Libert, R., J. Ruel, M. Ludgate, S. Swillens, N. Alexander, G. Vassart, and C. Dinsart. 1987. Thyroperoxidase, an auto-antigen with a mosaic structure made of nuclear and mitochondrial gene modules. EMBO (Eur. Mol. Biol. Organ.) J. 6:4193-4196.

19. Kimura, S., T. Kotani, O. W. McBride, K. Umeki, K. Hirai, T. Nakayama, and S. Ohtaki. 1987. Human thyroid peroxidase: complete cDNA and protein sequence. Proc. Natl. Acad. Sci. USA. 84:55555559.

20. Seto, P., H. Hirayu, R. P. Magnusson, J. Gestautas, L. Portmann, L. J. DeGroot, and B. Rapoport. 1987. Isolation of a cDNA clone for the thyroid microsomal antigen. Homology with the gene for thyroid peroxidase. J. Clin. Invest. 80:1205-1208.

21. Tzartos, S. J., A. Kokla, S. L. Walgrave, and B. M. ContiTronconi. 1988. Localization of the main immunogenic region of human muscle acetylcholine receptor to residues 67-76 of the $\alpha$ subunit. Proc. Natl. Acad. Sci. USA. 85:2899-2903.

22. Hohlfeld, R., K. V. Toyka, L. L. Miner, S. L. Walgrave, and B. M. Conti-Tronconi. 1988. Amphipathic segment of the nicotinic receptor alpha subunit contains epitopes recognized by $\mathrm{T}$ lymphocytes in myasthenia gravis. J. Clin. Invest. 81:657-660.

23. Han, J. H., C. Stratowa, and W. J. Rutter. 1987. Isolation of full-length putative rat lysophospholipase cDNA using improved methods for mRNA isolation and cDNA cloning. Biochemistry. 26:1617-1625.

24. Gubler, U., and B. J. Hoffman. 1983. A simple and very effcient method for generating cDNA libraries. Gene (Amst.). 2:263-269.

25. Ellis, L., E. Clauser, D. O. Morgan, M. Edery, R. Roth, and W. J. Rutter. 1986. Replacement of insulin receptor tyrosine residues 1162 and 1163 compromises insulin-stimulated kinase activity and uptake of 2-deoxyglucose. Cell. 45:721-732.

26. Maniatis, T., E. F. Fritsch, and J. Sambrook. 1982. Molecular Biology: A Laboratory Manual. Cold Spring Harbor Laboratory, Cold Spring Harbor, NY.

27. Chen, C., and H. Okayama. 1987. High-efficiency transformation of mammalian cells by plasmid DNA. Mol. Cell. Biol. 7:27452752.

28. Southern, P. J., and P. Berg. 1982. Transformation of mammalian cells to antibiotic resistance with a bacterial gene under control of the SV40 early region promoter. J. Mol. Appl. Genet. 1:327-341.

29. Chomczynski, P., and N. Sacchi. 1987. Single-step method of 
RNA isolation by acid guanidinium thiocyanate-phenol-chloroform extraction. Anal. Biochem. 162:156-159.

30. Bradford, M. M. 1976. Rapid and sensitive method for the quantitation of microgram quantities of protein utilizing the principle of protein-dye binding. Anal. Biochem. 72:248-254.

31. Laemmli, U. K. 1970. Cleavage of structural proteins during the assembly of the head of bacteriophage T4. Nature (Lond.). 227:680-689.

32. Young, R. A., and R. W. Davis. 1985. Immunoscreening lambda gt 11 recombinant DNA expression. In Genetic Engineering: Principals and Methods. Plenum Publishing Corp. 29-41.

33. Portmann, L., F. W. Fitch, W. Havran, N. Hamada, W. A. Franklin, and L. J. DeGroot. 1988. Characterization of the thyroid microsomal antigen, and its relationship to thyroid peroxidase, using monoclonal antibodies. J. Clin. Invest. 81:1217-1224.

34. Magnusson, R. P., and B. Rapoport. 1985. Modulation of differentiated function in cultured thyroid cells: thyrotropin control of thyroid peroxidase activity. Endocrinology. 116:1493-1500.

35. Chance, B., and A. C. Maehly. 1955. Assay of catalases and peroxidases. Methods Enzymol. 2:764-775.

36. Magnusson, R. P., A. Taurog, and M. L. Dorris. 1984. Mechanisms of thyroid peroxidase and lactoperoxidase-catalyzed reactions involving iodide. J. Biol. Chem. 259:13783-13790.

37. Hinds, W. E., N. Takai, B. Rapoport, S. Filetti, and O. H. Clark. 1981. Thyroid stimulating immunoglobulin bioassay using cultured human thyroid cells. J. Clin. Endocrinol. Metab. 52:1204-1210.

38. Ohtaki, S., T. Kotani, and Y. Nakamura. 1986. Characterization of human thyroid peroxidase purified by monoclonal antibodyassisted chromatography. J. Clin. Endocrinol. Metab. 63:570-576.
39. Ludgate, M., S. Mariotti, F. Libert, C. Dinsart, P. Piccolo, F. Santini, J. Ruf, A. Pinchera, and G. Vassart. 1989. Antibodies to human thyroid peroxidase in autoimmune thyroid disease: studies with a cloned recombinant complementary deoxyribonucleic acid epitope. J. Clin. Endocrinol. Metab. 68:1091-1096.

40. Hamada, N., C. Grimm, H. Mori, and L. J. DeGroot. 1985. Identification of a thyroid microsomal antigen by Western blot and immunoprecipitation. J. Clin. Endocrinol. Metab. 61:120-128.

41. Hamada, N., L. Portmann, and L. J. DeGroot. 1987. Characterization and isolation of thyroid microsomal antigen. J. Clin. Invest. 79:819-825.

42. Nagayama, Y., S. Yamashita, H. Hirayu, M. Izumi, T. Uga, N. Ishikawa, K. Ito, and S. Nagataki. 1989. Regulation of thyroid peroxidase and thyroglobulin gene expression by thyrotropin in cultured human thyroid cells. J. Clin. Endocrinol. Metab. 68:1155-1159.

43. Yokoyama, N., and A. Taurog. 1988. Porcine thyroid peroxidase: relationship between the native enzyme and an active, highly purified tryptic fragment. Mol. Endocrinol. 2:838-844.

44. Gardas, A., and H. Domek. 1988. The effect of sulphydryl reagents on the human thyroid microsomal antigen. $J$. Endocrinol. Invest. 11:385-388.

45. Nakajima, Y., R. D. Howells, C. Pegg, E. D. Jones, and B. R. Smith. 1987. Structure-activity analysis of microsomal antigen/thyroid peroxidase. Mol. Cell. Endocrinol. 53:15-23.

46. Davies, T. F., C. M. Weber, P. Wallack, and M. Platzer. 1986. Restricted heterogeneity and $\mathrm{T}$ cell dependence of human thyroid autoantibody immunoglobulin G subclasses. J. Clin. Endocrinol. Metab. 62:945-949. 